\title{
From Emotional Orphanhood to Cultural Orphanhood: Spiritual Death and Re-birth in Two Novels by Toni Morrison
}

\author{
Susana Vega González \\ Universidad de Oviedo
}

\begin{abstract}
This paper aims to analyze the process of spiritual death and sometimes ensuing re-birth Morrison's characters undergo in two of her novels: Sula and Tar Baby. Special attention will be paid to the female protagonists, Sula and Jadine, and their emotional and cultural "orphanhood" caused by their detachment from the ancestors and the community. Neither a total detachment nor an unquestioning submission to the establishment within the community is convenient; Morrison's eclectic position in this sense will be explained through this analysis.
\end{abstract}

Only when you drink from the river of silence shall you indeed sing. And when you have reached the mountain top, then you shall begin to climb. And when the earth shall claim your limbs, then shall you truly dance.

Kahlil Gibran, The Prophet

No Black woman should apologize for being educated or anything else. The problem is not paying attention to the ancient properties.

Toni Morrison

Death is life and life is death, evil is good and good is evil, past is present and present is past.... These are the contradictory binaries Toni Morrison deals with throughout her novels. This paper will concentrate on the first "opposition" life/death and especially, on 
her treatment of spiritual death and re-birth. Morrison's MA thesis on alienation and suicide in William Faulkner and Virginia Woolf shows her early interest in this subject. Such interest continues in all her later works, two of which $\neg$ Sula (1973) and Tar Baby (1981)--will be the focus of this analysis. Morrison dives into the abyss of death not only by means of direct allusions to it but also by a wide range of symbolic references and metaphors.

The author of six novels, a book of literary criticism and a play, Toni Morrison is the first African-American female writer in the United States who received the Nobel Prize for Literature, awarded her in 1993. She had previously won the Pulitzer Prize in 1988 for Beloved; her second novel, Sula, had been nominated for the National Book Award in 1975 and her third novel, Song of Solomon, had won the National Book Critic's Circle Award and the American Academy and Institute of Arts and Letters Award in 1977. From her very first work, published in 1970 and with such a telling title as The Bluest Eye, Morrison stood out as a promising skilled writer and, throughout her career, she has been highly acclaimed and seriously recognized as one of the most prominent contemporary exponents of the African-American experience. She belongs to a group of AfricanAmerican women writers who, from the 1970s, have engaged in the arduous enterprise of making their voices heard. Names like Alice Walker, Paule Marshall, Gloria Naylor, Toni Cade Bambara, Gayl Jones, and Audre Lorde, among others, have empowered the figure of the black woman from the position of object into that of subject in the white male canon. Morrison's novels deal with the suffering, pain, and hope of the black community and of the black woman within it. She writes about race and gender, with a special focus on the healing recovery of the African-American past. The ancestors, the supernatural, the family, the relationship between generations and the bonding of friendship among women come to the fore in the narrative of this writer who presents us with untold stories that should pass on.

For Morrison, spiritual death is the consequence of the negation of a culture and a community. The ensuing cultural alienation is also the result of the influence and dominance exerted by the white race on the black race, which ends up losing selfconfidence and believing themselves as inferior as their white fellow human beings proclaim. Therefore, they try to adopt white values to the detriment of their own cultural heritage. This is what happens in the case of Jadine, the female protagonist of Tar Baby, who has been defined as a "cultural orphan" (Mobley 284) as opposed to the character that gives name to the novel Sula, who is instead described as an "emotional orphan" (Rubenstein 132). Both Jadine and Sula experience a spiritual death but in a different manner. While Jadine detaches herself from her black community and culture to immerse in the white world, Sula moves away from her community just to delve into herself and to be completely free from the traditional ties imposed on women, namely marriage, childbearing and a deep respect due to the community and the ancestors. Jadine fights for her assimilation to the white culture whereas Sula struggles for her independence without claiming racial assimilation.

Jadine is an attractive young woman whose successful career as a model in Europe, her degree in Art from the Sorbone and her relationship with a well-off white lawyer who wants to marry her seem to be the right ingredients for a promising future. She is portrayed 
as the negation of a racial ancestral consciousness and her orphanhood is twofold: she lost her parents as a child and she lost her connection to what Morrison calls "the ancient properties" as an adult. "Jadine is everything integration aims to produce. Fully assimilated into white American culture, she should be wonderful; instead, she is tragic, because 'she has lost the original and ancient characteristics of her tribe"' (Strouse 53). ${ }^{1}$ When Jadine visits the Caribbean Isle des Chevaliers to spend some days with her uncle, she encounters a series of cultural conflicts with Son, a runaway from the United States whose very name links him to the ancestors. From the beginning Son is seen by Jadine as the black savage who threatens her security and assimilation but, after a time they end up being lovers. On one occasion Son addresses her with scathing words of reproach: "Why do you little white girls think somebody's trying to rape you?," to which Jadine, frightened by the unveiling of her truth, answers, "White? ... I'm not ... you know I'm not white!" (121). Despite this desperate statement, she is conscious of her adopted whiteness, however dark her skin may be. Son, who was at the beginning the serpent who trespasses on Paradise is now the Saviour who tries to redeem Jadine of her spiritual death. He desperately tries to make her realize that she turns "little black babies into little white ones," that she turns her "black brothers into white brothers" and her "men into white men" (270). But his efforts are to no avail.

The reason Jadine leaves Paris in the first place is her fear of the image of a black woman in a yellow dress who spits at her one day on the street. This woman represents Jadine's alter ego, that is, her black self from which she tries to escape. But even after leaving she is still haunted by threatening visions of ancestral women. When she makes love to Son, her privacy is disturbed by a group of women in her imagination: her dead mother, her aunt, Son's dead wife, and the woman in yellow. All of them, except the last one, symbolically exhibit their breasts to her, while the woman with the yellow dress shows her three eggs. These women clearly represent threatening maternal figures of fertility which remind Jadine of both her womanhood and her connection to the figure of the mother and, in turn, that of the ancestor. This connection to her origins endangers her independence and freedom in her adopted white world. On another occasion we can see Jadine walking through the trees when she gradually sinks into a pool of tar. In an attempt to liberate herself, she holds on to one of the trees but, again, from them hang menacingly the group of ancestral women who "were delighted when first they saw her, thinking a runaway child had been restored to them. But upon looking closer they saw differently. This girl was fighting to get away from them ... they wondered at the girl's desperate struggle down below to be free, to be something other than they were" (183). The "black stuff' (184) which covered Jadine's legs is the tar the women hanging from the trees represent. The symbolism of the tar is explained by Morrison in one of her interviews: "At one time, a tar pit was a holy place, at least an important place, because tar was used to build things. It came naturally out of the earth; it held together things like Moses's little boat and the pyramids. For me, the tar baby came to mean the black woman who can hold things together" (Leclair 372). However, Jadine sees these women as representative of an obsolete system and culture. Being physically trapped in the pool of tar feels like being psychologically trapped in an obsolete ancestral world. Thus the night women threaten to "grab the person she had worked hard to become and choke it off with thier soft loose tits" 
(262). She has made up her mind not to be like the other women who, like her aunt Ondine, think that if a girl "never learns how to be a daughter, she can't never learn how to be a woman" and that "a daughter is a woman that cares about where she come from and takes care of them that took care of her" (281).

The relationship between Son and Jadine is based on a mutual desire to change the attitude of the other. If Son tries to save her from her spiritual death, she in turn tries to "convert" him to her material world of grandeur. This is why she takes him to her beloved New York City. There Son is obviously out of his element and feels stifled by that kind of city life which annihilates all communal relationship between the black man and woman and does not pay the necessary attention to the old. New York leaves much to be desired for Son, who would not change his birthplace, Eloe, for anything. When Jadine visits Son's town later on, she has a parallel reaction to that of her lover in the City: Eloe is like a nightmare for her, a lifeless, "rotten," "burnt-out place" (259). In the end neither Son nor Jadine changes. Son reaffirms his ancestral beliefs when he tells Jadine, "You're not from anywhere. I'm from Eloe" (266), and Jadine finally goes back to Paris. As Terry Otten puts it, "The contraries cannot coexist, though, and neither character proves capable of integrating the opposite" (75). However, after her departure Son experiences a slight fluctuation of his deeply rooted cultural compromise and, because of his love for her, he even thinks of giving up everything to follow her. But old Thérèse, a descendant of the black horse riders that used to live on the island, discourages him. The figure of this woman is crucial at this point, for it is her wisdom that advises Son to forget Jadine and then gives him the possibility of choosing between going to Paris or staying at home, with the black riders. The final choice represents Son's symbolic re-birth after his momentary indecisiveness: by deciding to stay and search for the horse riders, he is affirming and strengthening his ties to the ancestors. The image of re-birth can be clearly seen in the progressive steadiness of Son's steps; from crawling like a baby he ends up running in the direction of personal fulfillment:

First he crawled the rocks one by one, one by one, till his hands touched shore and the nursing sound of the sea was behind him. He felt around, crawled off and then stood up. Breathing heavily with his mouth open he took a few tentative steps. The pebbles made him stumble and so did the roots of trees. He threw out his hands to guide and steady his going. By and by he walked steadier, now steadier ... Then he ran. (306)

Tar Baby represents a good example of cautionary tale because of its final moral and its exposure of the mistaken behaviour of a particular character, in this case Jadine, and the consequences such behaviour brings about. Her college education does not fill in the gap created by her racial, cultural ignorance. Forgetting her "ancient properties" (305), she runs away from the pool of tar where the ancestral women are only to sink into a deeper and much darker one: the pool of oblivion and spiritual death.

Beginning and ending merge in circles of sorrow in Sula. The destruction of Nature by man portrayed on the first pages leads to the final destruction of the people of a 
community. This novel is fraught with images of death and destruction. The very celebration of the local festivity is surrounded by them. Shadrack, a demented man who was a soldier during World War $\mathrm{I}$, is convinced that he can manipulate and dominate death, so he decides to create the so-called National Suicide Day as the local festivity of The Bottom--the neighbourhood where the story takes place. With this annual celebration, everyone will be "allowed" to either commit suicide or murder only once a year. Thus death will not be unexpected any more but a natural phenomenon that can be controlled:

It had to do with making a place for fear as a way of controlling it. He knew the smell of death and was terrified of it, for he could not anticipate it. It was not death or dying that frightened him, but the unexpectedness of both. In sorting it all out, he hit on the notion that if one day a year were devoted to it, everybody could get it out of the way and the rest of the year would be safe and free. (14)

The community of The Bottom assumes the death ritual that their festivity involves. They accept death as a natural phenomenon, one more stage in the human existence, the same as the presence of good and evil: "Plague and drought were as 'natural' as springtime ... The purpose of evil was to survive it and they determined ... to survive floods, white people, tuberculosis, famine and ignorance" (90). In the same way as the black community in The Bottom is determined to fight and survive evil, they also esteem it necessary to do the same with any incarnation of evil even if it is a member of their own community, namely Sula.

Sula is described by Morrison as "rule-breaker," "lawless woman," "not the run-of-themill average woman," and "an artist with no art form." Like Jadine, Sula refuses to abide by the obsolete rules of a closed community which restrict her personal freedom. As Carolyn Denard argues, "Jadine and Sula are Morrison's objectors" (173). Both are against the traditional roles assigned to the black woman of submissive mother and housewife. However, in their fierce longing for freedom and selfhood they forget the necessity to keep a link with the ancestors and the other members of the community. From the beginning Sula appears "marked" as different because of her birthmark, whose diverse interpretations emphasize the various faces of her personality and nature. This birthmark sometimes looks like a rose, symbolizing Sula's passion toward both her own experimental life and her lovers; it also appears as a tadpole, which could stand for her lack of maturity that the community sees in her; ${ }^{2}$ as a snake the birthmark represents, on the one hand, the evil embodied in Sula and, on the other hand, the re-birth she experiences at the end, undergoing a similar process to that of the snakes when they slough their skin in regeneration. Finally, the birthmark is aiso seen in the novel as Hannah's ashes, thus stigmatizing Sula as an evil being who watches impassively her mother's death by fire.

In contrast to Sula appears her righteous friend Nel Wright "who ... embodies the myth of the black woman as a nurturing, self-sacrificing, infinitely strong burden bearer" (Krumholz 554). The relationship between the two symbolizes the close relationship between good and evil. Sula turns into a pariah in her village and is used as a scapegoat for all their misfortunes. Her process of alienation from the community stems from her feelings of detachment from her own mother when she overhears her saying that she loves 
her daughter but does not like her; because of these words Sula will be later convinced that "there was no other that you could count on" (118). But this is not the only blow that hits our protagonist during her early adolescence for it is also at this time that she experiences her first encounter with death. While playing with a child called Chicken Little and her friend Nel, she accidentally throws him into a river, where he drowns. This death by water, which is interpreted by critics like Barbara Christian as Sula's baptism into maturity (Christian 82), is followed by Sula's second encounter with death: that of her mother. This fatal event is preceded by a series of "strange things" about which Morrison says in an interview, "If I'm talking about death, you should know to expect it because the omens alert you. The strange things are all omens" (Tate 124). The strong wind heralding a storm, Hannah's dream of a wedding where the bride wears a red dress, and the comb Eva, Sula's grandmother, cannot find are all silent announcers of Hannah's death. On the one hand, a wedding in dreams signifies death; on the other, the colour red of the bridal dress symbolizes the fire which will kill Hannah in an accident. Paradoxically, Sula's reaction as a witness of this second case of death is one of amazing coldness and passivity, as she watches her mother in flames without doing anything to help her, probably while Hannah's words of dislike about her daughter still linger on her mind. Sula's attitude can also be interpreted as her negation of maternity.

The image of the wedding associated with death appears again when Nel gets married. By so doing, Nel submits herself to the smothering of her personal freedom, thus becoming more distant from her girl friend's ideals of independence and adventure. This marriage then means death not only to Nel but also to the friendship between the two women. In fact, after Nel's wedding Sula leaves The Bottom. It will be ten years before she returns, "accompanied by a plague of robins ... flying and dying" (89). Also the four dead robins in front of Eva's house announce the return of the prodigal daughter. These dead birds represent Sula herself, who perishes in her attempt to keep "flying". The metaphor of the winged but grounded bird is accompanied here by the strong symbolism of the colour red of the robins, which is associated with Sula because of the danger she represents for the community. Her fierce determination to be "her" self and live "her" own life is emphasized by her constant use of possessive adjectives and pronouns like "mine," "me," "myself" when she says, "I want to make myself" (92), "Whatever's burning in me is mine!" (93), reaching the culmination of her self-definition with the words: "But my lonely is mine!" (93). Not only does Sula go against the rules of the community by asserting her self in this way, but also by putting her old grandmother in a nursing home and by having a promiscuous sexual life. With all this the community is even more against her, hence her increasing loneliness.

The third and last encounter Sula has with death occurs when she herself dies of a fever in 1940. Such event is the best thing that could happen to the people of The Bottom. However, on this occasion death means a kind of life for Sula; in a way she has achieved what she always wanted: her personal freedom and independence. As opposed to the rest of the women, she has lived the life she desired and she is proud of that: "I know what every colored woman in this country is doing ... Dying. Just like me. But the difference is they dying like a stump. Me, I'm going down like one of those redwoods. I sure did live in this world" (143). The image of the redwood is crucial here as, being a perennial tree, 
it represents life and eternity. The death of the body releases the soul into life. The fact that Sula dies in the fetal position, with her thumb in her mouth, like a baby, and conjuring up images of water-reminiscent of the amniotic fluid-suggests her final spiritual re-birth:

It would be here, only here, held by this blind window high above the elm tree, that she might draw her legs up to her chest, close her eyes, put her thumb in her mouth and float over and down the tunnels, just missing the dark walls, down, down until she met a rain scent and would know the water was near, and she would curl into its heavy softness and it would envelop her, carry her, and wash her tired flesh always. (148-49)

This particular scene is analyzed in many different ways by some critics; Sula's fetal position can be seen as the protagonist's immaturity, as the negation of true freedom for Sula due to her anxious desire to define herself through exclusion from the community and, finally, as her self-absorption caused by the mutual rejection between Sula and her community (Guth 591). Nonetheless, the idea of re-birth seems to be the most plausible of all if we also take into account the previous allusions to eternity and immortality the image of the redwood suggests, apart from the clear references to a new life a foetus represents. Through death she finally achieves unconditional freedom, even freedom from her condition of pariah in the community. Selfhood is defined through absence. Sula's death, like her loneliness, is only "hers". Although Sula dies of a fever--heat and fire--the masculine element fire and the feminine element water blend in a representation of the fusion between the masculine part in Sula and the feminine side Nel epitomizes; both melt in perfect harmony. On her deathbed Sula cannot stop thinking about her old friend Nel, missing her. "Sula dies alone, but her dying comment 'Wait'll I tell Nel' (149) invokes 'the other half of her equation"' (Grant 100).

In keeping with the blurry line between good and evil that Morrison delineates in this novel, the death of the evil one spawns the death of the community itself. As Morrison argues, "one can never really define good and evil. Sometimes good looks evil; sometimes evil looks like good ... Evil is as useful as good is ..." (Stepto 381). The pariah's disappearance brings about the destruction of the whole community. Chaos and dislocation take hold of everything: crops destroyed by frozen weather, disease, relationship problems in the families.... The novel closes with a communal death of those who intend to boycott a tunnel built only by whites on the infamous National Suicide Day, with Shadrack at the head of the group. "Bottom is destroyed from within, a paradise already ruined by selfpossessiveness and moral certainty. The tunnel becomes a communal womb, a perverse symbol of aborted life. Suggestively, it is also a tunnel constructed by whites" (Otten 41). This collective death means, on the one hand, the suicide or self-annihilation of the black community brought about by their rejection of change and evolution and, on the other hand, the massacre of black people at the hands of the white race. This tragic event happened in 1941. Some years later, in 1965, the total destruction of The Bottom as a neighbourhood has been consummated. The tombs of black men and women remain faithful and only witnesses to such destruction.

After analyzing all these cases and images of death, we can conclude that what Morrison advocates is an eclectic position in the relationship between the community and 
each of its members. Extremes are not usually convenient, as Morrison clearly argues when talking about Sula and Nel:

Living totally by the law and surrendering completely to it without questioning anything sometimes makes it impossible to know anything about yourself. Nel doesn't even know what questions she's asking ... Sula, on the other hand, knows all there is to know about herself because she examines herself, she is experimental with herself ... But she has trouble making a connection with other people and just feeling that lovely sense of accomplishment of being close in a very strong way. (Stepto 381-82)

Sula and Tar Baby are exponents of one of Morrison's motifs in her narrative: the relationship between the black community as a whole and its members as individuals. The figure of the pariah stands out as a reminder of the dangers of both a hermetic community and the recalcitrant indifference to one's origins and ancestors. Both Jadine and Sula destroy their connection to the community. However, a substantial difference between these two cases determines the final outcome. By returning to Paris, Jadine is actually fleeing from herself and her racial heritage. Sula, on the other hand, returns to her people to stay, even in her condition of pariah. But it is the community that eventually grounds Sula forever, like the fallen robins that announced her return. While Jadine's choice of physical life in Paris brings about her spiritual annihilation, Sula's physical death ennables her to reach spiritual life and escape from the fetters of this world to be re-born into freedom.

Thus for Morrison, who sees the ancestors and the old, the community and its traditions as essential values for the black people, there must never be a total detachment from the cultural roots from which the black woman has stemmed, nor an absolute submission to the canon and the establishment within ${ }^{1}$ the community. Elaine Jordan makes the point: "Morrison celebrates communities; she also celebrates accepting love of the different one, the one on the edge, who lets 'us' know who we are...." (123).

\section{Notes}

1. The issue of racial assimilation is dealt with in other novels by contemporary AfricanAmerican women writers, such as Paule Marshall's Praisesong for the Widow and Gloria Naylor's Mama Day. These two works are highly representative of both the cultural alienation which stems from the lack of belief in one's own cultural heritage and racial identity and the need to come to terms with one's cultural and personal past as a restorative journey into the future.

2. Different interpretations from the one exposed here have been suggested by other critics. For Barbara Christian, the tadpole which Shadrack sees in Sula's birthmark implies the vision of the girl as a friend for him, since he is a fisherman (88); but it is precisely this reason and the fact that fish is "life-giving" for a fisherman that leads Dorothy $\mathrm{H}$. Lee to the conclusion that the tadpole symbolizes Sula's vitality and her representation as source of life (352). 


\section{Works cited}

Christian, Barbara. Black Women Novelists. The Development of a Tradition, 1892-1976. Westport: Greenwood, 1980.

Denard, Carolyn. "The Convergence of Feminism and Ethnicity in the Fiction of Toni Morrison." Critical Essays on Toni Morrison. Ed. Nellie McKay. Boston: G.K. Hall, 1988. 171-79.

Grant, Robert. "Absence into Presence: The Thematics of Memory and 'Missing' Subjects in Toni Morrison's Sula." Critical Essays on Toni Morrison. Ed. Nellie McKay. Boston: G. K. Hall, 1988. 90-103.

Guth, Deborah. "A Blessing and a Burden: The Relation to the Past in Sula, Song of Solomon and Beloved." Modern Fiction Studies 39.3, 4 (1993): 575-96.

Jordan, Elaine. “'Not My People': Toni Morrison and Identity." Black Women's Writing. Ed. Gina Wisker. New York: St. Martin's, 1993. 111-26.

Krumholz, Linda. "Dead Teachers: Rituals of Manhood and Rituals of Reading in Song of Solomon." Modern Fiction Studies 39.3, 4 (1993): 551-74.

Leclair, Thomas. "The Language Must Not Sweat': A Conversation with Toni Morrison." Toni Morrison, Critical Perspectives Past and Present. Ed. Henry Louis Gates, Jr. \& K. A. Appiah. New York: Amistad, 1993. 369-77.

Lee, Dorothy H. "The Quest for Self: Triumph and Failure in the Works of Toni Morrison." Black Women Writers (1950-1980). Ed. Mari Evans. London: Pluto, 1985. 346-60.

Mobley, Marilyn Sanders. "Narrative Dilemma: Jadine as Cultural Orphan in Tar Baby." Toni Morrison, Critical Perspectives Past and Present. Ed. Henry Louis Gates, Jr. \& K. A. Appiah. New York: Amistad, 1993. 284-92.

Morrison, Toni. Sula. New York: Quality Paperback, 1973. . Tar Baby. New York: Quality Paperback, 1981.

Otten, Terry. The Crime of Innocence in the Fiction of Toni Morrison. Columbia: $\mathrm{U}$ of Missouri P, 1989.

Rubenstein, Roberta. "Pariahs and Community." Toni Morrison, Critical Perspectives Past and Present. Ed. Henry Louis Gates, Jr. \& K. A. Appiah. New York: Amistad, 1993. 126-58.

Stepto, Robert B. "Intimate Things in Place': A Conversation with Toni Morrison.” Toni Morrison, Critical Perspectives Past and Present. Ed. Henry Louis Gates \& K. A. Appiah. New York: Amistad, 1993. 378-95.

Strouse, Jean. "Toni Morrison's Black Magic." Newsweek 30 March 1981: 52-57.

Tate, Claudia, ed. Black Women Writers at Work. Herts: Oldcastle, 1985. 